\title{
Milk and serum IL-4, IL-6, IL-10, and amyloid A concentrations in cows with subclinical mastitis caused by coagulase-negative staphylococci
}

\author{
Mariola Bochniarz, ${ }^{11}$ Barbara Zdzisińska,† Władysław Wawron, ${ }^{*}$ Marek Szczubiał, ${ }^{*}$ and Roman Dąbrowski* \\ *Department and Clinic of Animal Reproduction, Faculty of Veterinary Medicine, University of Life Sciences, Gleboka 30, 21-612 Lublin, Poland \\ †Department of Virology and Immunology, Maria Curie-Sklodowska University, Akademicka 19, 20-033 Lublin, Poland
}

\begin{abstract}
The aim of the study was to evaluate the concentrations of cytokines IL-4, IL-6, and IL-10 and acute phase protein amyloid A in milk and in serum from cows with subclinical mastitis caused by coagulase-negative staphylococci and from healthy cows. The blood and milk samples were obtained from 35 midlactation, multiparous (between parities 2 and 4) Holstein-Friesian cows. In the milk samples from 20 cows with subclinical mastitis, the following species of Staphylococcus were detected: Staphylococcus xylosus (8 samples), Staphylococcus chromogenes (6 samples), Staphylococcus haemolyticus (2 samples), Staphylococcus simulans (2 samples), and Staphylococcus sciuri (2 samples). The results of the present study indicate that the level of IL-6 in cows suffering from subclinical mastitis tended to be high in both serum and milk (432.09 and 254.32 $\mathrm{pg} / \mathrm{mL}$ ) compared with the level in healthy cows (164.47 and $13.02 \mathrm{pg} / \mathrm{mL}$, respectively). Amyloid A value also was significantly higher in milk of unhealthy cows compared with cows without subclinical mastitis (790.2 and $360.5 \mathrm{ng} / \mathrm{mL}$ ). No significant differences were found in levels of amyloid $\mathrm{A}$ in serum of both tested groups of cows $(2,680.0$ and 2,720.0 $\mathrm{ng} / \mathrm{mL})$. In contrast, concentration of IL-4 was significantly lower both in serum and in milk of cows with staphylococcal mastitis (86.1 and $123.17 \mathrm{pg} / \mathrm{mL}$ ) compared with control animals (413.5 and $670.2 \mathrm{pg} / \mathrm{mL}$ ). The level of IL-10 also was significantly higher in milk of healthy cows than in infected cows (39.78 and $22.5 \mathrm{pg} / \mathrm{mL}$ ); however, differences in serum levels of this cytokine between tested groups were significantly less important (220.6 and $175.1 \mathrm{pg} / \mathrm{mL}$ ).
\end{abstract}

Key words: subclinical mastitis, coagulase-negative Staphylococcus sp., acute phase response

Received July 24, 2017.

Accepted August 17, 2017.

${ }^{1}$ Corresponding author: mariolabochniarz@interia.pl

\section{INTRODUCTION}

Coagulase-negative staphylococci, which are widely spread in the natural environment, colonize the skin and mucous membranes in both animals and humans. For many years CNS were thought to be nonpathogenic; however, they have become the predominant pathogens of mastitis in cows in numerous countries (Makovec and Ruegg, 2003; Pyörälä and Taponen, 2009; Thorberg et al., 2009; Bochniarz et al., 2013). More than 15 strains of CNS are known and identified as etiological factors of mastitis (Waller et al., 2011; Tomazi et al., 2015).

The primary defense role of the mammary gland in the inflammatory process is the settling of leucocytes. The number of these is usually $<200,000$ cells $/ \mathrm{mL}$ of milk. When mastitis is present the cell count increases, primarily as a consequence of leukocyte infiltration. Inflamed neutrophils and macrophages phagocytize and kill the absorbed bacteria and remove cellular aggregates (Niemiałtowski et al., 1988; Paape et al., 2003).

The acute phase reaction is an element of nonspecific resistance and manifests with a rapid increase in the production of proteins, which are recognized as a marker of inflammation in mammals (Eckersall et al., 2001; Murata et al., 2004). One of the acute phase proteins (APP) is serum amyloid A (SAA), which is an apoprotein that is part of the high-density lipoprotein (Eklund et al., 2012). The role of SAA is to inhibit lymphocyte and endothelial cell proliferation, platelet aggregation, and phagocytosis. It also stimulates the migration of monocytes and neutrophils and the synthesis of prostaglandins and metalloproteinases (Petersen et al., 2004). Serum amyloid A mRNA transcription (SAA1 and SAA2 isoforms) is carried out mainly in hepatocytes under the influence of IL-1 $\alpha$, IL-6, and tumor necrosis factor- $\alpha$ (Berg et al., 2011). Previous studies of cows with mastitis have shown that SAA concentrations are significantly increased ( $>200$ times) during acute mammary infection. Serum amyloid A is regarded as the most sensitive APP in cows (Eckersall et al., 2001; Murata et al., 2004; Nielsen et al., 2004) 
and in ewes (Winter et al., 2006), but it does not correlate with subclinical mastitis (Miglio et al., 2013).

Extrahepatic SAA mRNA expression (SAA isoform 3) occurs in the mammary gland. The transcription site of the amyloid A isoform gene [milk amyloid A (MAA), SAA3, AA3, M-SAA3] contained in milk is the mammary epithelial cells. Milk amyloid A has at the $\mathrm{N}$ end of the sequence 4 TFLK (a conserved $4 \mathrm{AA}$ motif) AA regardless of species (horse, cow, sheep) that are absent in the isoform of the liver synthesis protein. In cattle, MAA contains $83 \%$ of the same AA sequence as SAA (McDonald et al., 2001). High levels of MAA in cows with mastitis have been reported in earlier studies (Petersen et al., 2004; Berry et al., 2005; Kováč et al., 2011; Kovačević-Filipović et al., 2012).

The main role of the acute phase reaction is to restore homeostasis in the organism by stimulating immune mechanisms. The interaction of various cellular and humoral immune response mechanisms is based on the transmission of cytokine stimulatory or inhibitory signals. Interleukin-6, which is considered to be the strongest stimulator of production and secretion of APP, plays a particularly important role (Song and Kellum, 2005). This cytokine is expressed by a variety of cells, including lymphocytes, monocytes, macrophages, endothelial cells, epithelial cells, and fibroblasts, and its expression is induced by bacteria. Interleukin- 6 has an influence on the concentration of transferrin, ceruloplasmin, and haptoglobin. In addition, it participates in T-cell antigen recognition activation and cytotoxic T-cell differentiation and acts as a stimulant for B-cell differentiation into Ig-releasing cells of various classes. Interleukin- 6 works mainly on lymphocytes stimulated by different cytokines - among others, IL-4 (Scheller et al., 2011; Ezzat Alnakip et al., 2014). Increased concentrations of IL- 6 have been detected in both the milk and blood of cows with naturally acquired and experimentally induced mastitis as well as those infused with bacterial LPS (Shuster et al., 1993; Hagiwara et al., 2001). An extremely important advantage of IL-6 is its ability to persist in the circulation for a longer period of time than other proinflammatory cytokines (Song and Kellum, 2005).

Further inflammation is regulated by IL-10, which plays a central role in limiting this process by inhibiting the production of cytokines by stimulated cluster of differentiation (CD) $4^{+}$Th1 helper cells and inhibiting cytotoxic effects of monocytes and macrophages as well as synthesis of proinflammatory cytokines and APP. Because of that, IL-10 has been recognized as a major suppressor of the immune response and inflammatory activity (Kjelgaard-Hansen et al., 2007; Dąbrowski et al., 2015). In human medicine, it has been reported that an imbalance between IL-6 and IL-10 could contribute to the development of multiple organ dysfunction (Loisa et al., 2003). The aim of the study was to evaluate the concentrations of proinflammatory cytokine IL-6, anti-inflammatory cytokine IL-10, postinflammatory cytokine IL-4, and the APP MAA and SAA from cows with subclinical mastitis caused by CNS and from healthy cows.

\section{MATERIALS AND METHODS}

The selection of cows for evaluation of levels of cytokines (IL-4, IL-6, and IL-10) and APP (MAA and SAA) was performed on the basis of a clinical examination of cows and a bacteriological test of milk. The blood and milk samples were obtained from 20 midlactation, multiparous (between parities 2 and 4) Holstein-Friesian cows from 5 herds in various housing systems (4 freestall or loose and 1 tiestall) in the Lublin region in Poland. No clinical signs of mastitis were found in the cows selected for the study, but CNS species were isolated from the milk samples collected from them. The SCC of the milk from these cows ranged from 450,000 to 980,000 cells $/ \mathrm{mL}$. Cows were milked twice a day and had daily milk yields of 16.5 to $51.2 \mathrm{~kg}$ (median = $30.2 \mathrm{~kg}$ ). According to the parameters of the subclinical mastitis group, 15 healthy cows were selected that did not show any clinical signs of mastitis or abnormalities in the udder or milk. The healthy status was confirmed by negative bacteriological examination and low average SCC $(<100,000$ cells $/ \mathrm{mL})$. Clinical examination of cows and macroscopic evaluation of milk were carried out before collection of milk samples for bacteriological testing. In the study, cows did not receive any medicine during the ongoing lactation.

Milk was bacteriologically tested according to the generally accepted procedures. Milk samples brought to room temperature were thoroughly mixed and cultured on agar medium (BTL, Łódź, Poland) supplemented with sterile, defibrinated sheep blood (5\% of the agar solution volume). After $24 \mathrm{~h}$ of incubation at $37^{\circ} \mathrm{C}$ in aerobic conditions, pathogens were initially identified based on colony morphology and Gram-stained microscopic specimens.

Identification of CNS species was performed using a commercial API STAPH test (bioMérieux, Marcy L'Etoile, France) based on determinations of 19 biochemical features of bacteria. The procedure followed the manufacturer's recommendations (http:// biomerieux-usa.com/clinical/api).

Classification of forms of mastitis was conducted according to the generally accepted rules (Gentilini et al., 2002; De Vliegher et al., 2003; Moon et al., 2007), which are based on clinical examination of the cows, 
milk bacteriological testing, and SCC in the samples of milk. The SCC was measured in fresh milk by fluoroopto-electronic cell counting (SomaCount FC Automatic, Bentley Instruments, Chaska, MN). An SCC of $>200,000$ cells $/ \mathrm{mL}$ of milk and the presence of bacteria in bacteriological inoculation of milk (regarding the lack of general symptoms coming from the cow's organism) were considered subclinical mastitis. After SCC analysis, milk and serum samples were frozen at $-20^{\circ} \mathrm{C}$ and were stored at $-70^{\circ} \mathrm{C}$ until analysis of IL-4, IL-6, IL-10, SAA, and MAA.

\section{Measurements of Cytokines in Serum and Quarter Milk Samples}

The concentrations of cytokines in blood serum and quarter milk samples were determined using commercially available kits for IL-4, IL-6, and IL-10 (USCN Life Science Inc., Houston, TX). All procedures were performed according to the guidelines provided by the manufactures and methods in the literature (Hagiwara et al., 2001). Absorbance readings were performed on an automatic microtiter plate reader (ELx800, Biotek Instruments, Winooski, VT) at $450 \mathrm{~nm}$ using $630 \mathrm{~nm}$ as a reference. The detection ranges of IL-4, IL-6, and IL-10 for cattle were 15.6 to $1,000,1.56$ to 100 , and 15.6 to $1,000 \mathrm{pg} / \mathrm{mL}$, respectively, as reported by the manufacturer. The inter- and intra-assay coefficients of variation for all examined cytokines were $<12$ and $<10 \%$, respectively.

\section{Measurements of APP in Serum and Quarter Milk Samples}

Determination of SAA level was performed using an ELISA kit (USCN Life Science Inc.) with a detection range of 0.156 to $10 \mathrm{ng} / \mathrm{mL}$. Concentration MAA in quarter milk samples was determined by immunoassay using a commercially available ELISA method (Phase milk amyloid A assay kit; Tridelta Development Ltd., Maynooth, Ireland). For milk samples, the working range of 0.438 to $7.5 \mu \mathrm{g} / \mathrm{mL}$ takes the $1: 50$ dilution into account. Procedures were performed according to the manufacturer's instructions and literature methods (Eckersall et al., 2001; Suojala et al., 2008; Tóthová et al., 2014). Absorbance readings were performed on an automatic microtiter plate reader (ELx800, Biotek Instruments) at $450 \mathrm{~nm}$ using $630 \mathrm{~nm}$ as a reference. The results were calculated with a standard curve. Lyophilized bovine acute phase serum was used as a standard; calibration was performed according to the European Union concerted action on standardization of animal APP (no. QLK5-CT-1999-0153; Suojala et al., 2008).
All assays were performed at the Independent Medical Biology Unit, Medical University of Lublin, Poland.

\section{Statistical Analysis}

Statistical methods were used to compare IL-4, IL-6, IL-10, SAA, and MAA levels in serum and milk from cows with subclinical mastitis caused by CNS and from healthy cows. For the tested groups of cows, the statistical parameters were calculated: minimum and maximum values, mean and median values, and standard deviation. In a Shapiro-Wilk test there was no normal distribution of characteristic values in each group, so the Mann-Whitney test was used to compare these characteristics for 2 independent trials. A value of $P<$ 0.05 was considered significant. The calculations were performed using the statistical package Statistica 12.0 (StatSoft Inc., Tulsa, OK).

\section{RESULTS}

A total of 35 quarter milk samples were examined from 35 cows selected for testing. In the milk samples from 20 cows with subclinical mastitis, the following species of Staphylococcus were detected: Staphylococcus xylosus (8 samples), Staphylococcus chromogenes (6 samples), Staphylococcus haemolyticus (2 samples), Staphylococcus simulans (2 samples), and Staphylococcus sciuri (2 samples). In the bacteriological examination of milk from healthy cows, no growth of any microorganisms was observed.

In quarter milk samples for cows with subclinical mastitis and healthy cows, the SCC of the control group ranged from 3 to $80 \times 10^{3}$ cells $/ \mathrm{mL}$ (mean $=28.3$ cells $/$ $\mathrm{mL}$ ), whereas the SCC of the subclinical mastitis group ranged from 450 to $980 \times 10^{3}$ cells $/ \mathrm{mL}($ mean $=695.2$ cells $/ \mathrm{mL}$ ) of milk. The results of the levels of cytokines such as IL-4, IL-6, and IL-10 in the milk and blood serum of cows with subclinical mastitis caused by CNS and healthy cows are presented in Tables 1,2 , and 3 .

The results of the present study indicate that the level of IL-6 in cows suffering from subclinical mastitis tended to be high in both serum and milk (423.09 and $254.32 \mathrm{pg} / \mathrm{mL}$ ) compared with the level in healthy cows (164.47 and $13.02 \mathrm{pg} / \mathrm{mL} ; P<0.001$ ). In contrast, the concentration of IL-4 was significantly lower both in serum and in milk of cows with staphylococcal mastitis (86.1 and $123.17 \mathrm{pg} / \mathrm{mL}$ ) compared with healthy cows (413.5 and $670.2 \mathrm{pg} / \mathrm{mL} ; P<0.001$ ). The level of IL10 also was higher in milk from control cows than in milk from sick cows (39.78 and $22.5 \mathrm{pg} / \mathrm{mL} ; P<0.01$ ); however, differences in the value of this cytokine in the serum of tested groups were significantly less important (220.6 and $175.1 \mathrm{pg} / \mathrm{mL} ; P<0.05)$. 
Table 1. Concentration of IL-6 $(\mathrm{pg} / \mathrm{mL})$ in milk and serum from cows with subclinical mastitis caused by CNS and from healthy cows

\begin{tabular}{lcccr}
\hline Item & $\mathrm{n}$ & Median & Range & SD \\
\hline Milk & & & & \\
CNS cows & 20 & $254.32^{\mathrm{a}}$ & $39.74-590.53$ & 171.76 \\
Healthy cows & 15 & $13.02^{\mathrm{Ac}}$ & $2.4-217.2$ & 62.64 \\
Serum & & & & \\
CNS cows & 20 & $423.09^{\mathrm{b}}$ & $121.65-651.97$ & 149.43 \\
Healthy cows & 15 & $164.47^{\mathrm{BC}}$ & $99.57-483.55$ & 121.88 \\
\hline
\end{tabular}

${ }^{\mathrm{a}, \mathrm{A}}$ Refers to significant differences in IL- 6 concentration in milk between CNS and healthy cows $(P<0.001)$.

${ }^{\mathrm{b}, \mathrm{B}}$ Refers to significant differences in IL- 6 concentration in serum between CNS and healthy cows $(P<0.001)$.

${ }^{\mathrm{c}, \mathrm{C}}$ Refers to significant differences in IL-6 concentration between milk and serum in healthy cows $(P<0.001)$.

The data show that the concentrations of IL- 6 and IL-10 in healthy cows were definitely higher in serum (164.47 and $220.6 \mathrm{pg} / \mathrm{mL}$ ) than in milk (13.02 and $39.78 \mathrm{pg} / \mathrm{mL} ; P<0.001)$. Only in IL-4 was there a lower concentration of this cytokine in serum than in milk (413.5 and $670.2 \mathrm{pg} / \mathrm{mL} ; P<0.01$ ). In the case of cows with subclinical mastitis, there were no statistically significant differences in concentrations of IL-6 and IL- 4 between serum ( 423.09 and $86.1 \mathrm{pg} / \mathrm{mL})$ and milk (254.32 and $123.17 \mathrm{pg} / \mathrm{mL} ; P>0.05)$. However, in this group of cows, a significantly higher level of IL10 was recorded in serum $(175.1 \mathrm{pg} / \mathrm{mL})$ than in milk $(22.5 \mathrm{pg} / \mathrm{mL} ; P<0.001)$.

The results of the levels of APP MAA and SAA in the milk and blood serum of cows with subclinical mastitis caused by CNS and healthy cows are presented in Table 4. The MAA value was significantly higher in milk from unhealthy cows compared with milk from cows without subclinical mastitis (790.2 and $360.5 \mathrm{ng} /$ $\mathrm{mL} ; P<0.001)$. No significant differences were found

Table 2. Concentration of IL-10 (pg/mL) in milk and serum from cows with subclinical mastitis caused by CNS and from healthy cows

\begin{tabular}{lccrc}
\hline Item & $\mathrm{n}$ & Median & \multicolumn{1}{c}{ Range } & $\mathrm{SD}$ \\
\hline Milk & & & & \\
CNS cows & 20 & $22.5^{\mathrm{ac}}$ & $4.13-82.0$ & 16.86 \\
$\quad$ Healthy cows & 15 & $39.78^{\mathrm{Ad}}$ & $20.5-86.73$ & 22.51 \\
Serum & & & & \\
CNS cows & 20 & $175.1^{\mathrm{bC}}$ & $43.1-307.0$ & 79.03 \\
Healthy cows & 15 & $220.6^{\mathrm{BD}}$ & $127.1-404.9$ & 88.19 \\
\hline
\end{tabular}

\footnotetext{
${ }^{a, A}$ Refers to significant differences in IL-6 concentration in milk between CNS and healthy cows $(P<0.01)$.

${ }^{\mathrm{b}, \mathrm{B}}$ Refers to significant differences in IL-6 concentration in serum between CNS and healthy cows $(P<0.05)$.

${ }^{\mathrm{c}, \mathrm{C}}$ Refers to significant differences in IL-6 concentration between milk and serum in CNS cows $(P<0.001)$.

${ }^{\mathrm{d}, \mathrm{D}}$ Refers to significant differences in IL-6 concentration between milk and serum in healthy cows $(P<0.001)$.
}

Table 3. Concentration of IL-4 (pg/mL) in milk and serum from cows with subclinical mastitis caused by CNS and from healthy cows

\begin{tabular}{lcccr}
\hline Item & $\mathrm{n}$ & Median & Range & SD \\
\hline Milk & & & & \\
CNS cows & 20 & $123.17^{\mathrm{a}}$ & $5.06-510.02$ & 125.42 \\
Healthy cows & 15 & $670.2^{\mathrm{Ac}}$ & $253.91-1,110.44$ & 222.27 \\
Serum & & & & \\
CNS cows & 20 & $86.1^{\mathrm{b}}$ & $32.4-316.8$ & 81.79 \\
Healthy cows & 15 & $413.5^{\mathrm{BC}}$ & $33.5-1,213.0$ & 341.96 \\
\hline
\end{tabular}

${ }_{\mathrm{a}, \mathrm{A}}$ Refers to significant differences in IL-6 concentration in milk between CNS and healthy cows $(P<0.001)$.

${ }^{\mathrm{b}, \mathrm{B}}$ Refers to significant differences in IL-6 concentration in serum between CNS and healthy cows $(P<0.001)$.

${ }^{c, \mathrm{C}}$ Refers to significant differences in IL-6 concentration between milk and serum in healthy cows $(P<0.01)$.

in SAA values in serum of both tested groups of cows $(2,680.0$ and $2,720.0 \mathrm{ng} / \mathrm{mL} ; P>0.05)$. The data show that the concentration of amyloid A both in cows with subclinical mastitis and in healthy cows was definitely higher in serum $(2,680.0$ and $2,720.0 \mathrm{ng} / \mathrm{mL})$ compared with milk (790.2 and $360.5 \mathrm{ng} / \mathrm{mL} ; P<0.001$ ).

\section{DISCUSSION}

The aim of the study was to evaluate the concentrations of proinflammatory cytokine IL-6, anti-inflammatory cytokine IL-10, postinflammatory cytokine IL-4, and APP amyloid A in milk and in serum from cows with subclinical mastitis caused by CNS and from healthy cows. Serum amyloid A is the main APP in cows. This protein is produced in the liver and secreted in blood serum in response to proinflammatory cytokines, and its level increases during inflammation (Grönlund et al., 2003). The study conducted by Gerardi et al. (2009) showed a tendency for higher SAA concentration in cows with clinical mastitis, although

Table 4. Concentration of amyloid A $(\mathrm{ng} / \mathrm{mL})$ in milk and serum from cows with subclinical mastitis caused by CNS and from healthy cows

\begin{tabular}{lcccc}
\hline Item & $\mathrm{n}$ & Median & Range & $\mathrm{SD}$ \\
\hline Milk amyloid A & & & & \\
CNS cows & 20 & $790.2^{\mathrm{ab}}$ & $450.5-2,263.0$ & 439.70 \\
Healthy cows & 15 & $360.5^{\mathrm{Ac}}$ & $149.5-529.0$ & 108.76 \\
Serum amyloid A & & & & \\
CNS cows & 20 & $2,680.0^{\mathrm{B}}$ & $1,920.0-4,120.0$ & 680.64 \\
Healthy cows & 15 & $2,720.0^{\mathrm{C}}$ & $1,480.0-3,780.0$ & 637.14 \\
\hline
\end{tabular}

${ }^{a, A}$ Refers to significant differences in IL-6 concentration in milk between CNS and healthy cows $(P<0.001)$.

${ }^{\mathrm{b}, \mathrm{B}}$ Refers to significant differences in IL-6 concentration between milk and serum in CNS cows $(P<0.001)$.

${ }^{c, C}$ Refers to significant differences in IL-6 concentration between milk and serum in healthy cows $(P<0.001)$. 
these differences were not statistically significant $(P$ $=0.2$ ). In the research conducted by Eckersall et al. (2001), significant differences in concentration of SAA in cows with both mild and moderate mastitis compared with healthy cows were recorded, whereas there were no significant differences between the groups of mastitis in cows. On the other hand, Kovačević-Filipović et al. (2012) reported levels of SAA in serum of cows with Staphylococcus aureus subclinical mastitis that were 3 times higher than those from the control group of cows (87.1 and $24.4 \mu \mathrm{g} / \mathrm{mL}$, respectively). Perhaps such significant differences in SAA concentrations result from the duration or the degree of severity of the disease symptoms in the course of the inflammatory process. Winter et al. (2006) showed that after the experimental infection of the udder in sheep, concentration of SAA reached at a very rapid rate a high level that lasted for a relatively short period of time $(2-7 \mathrm{~d})$ and then returned to physiological values even when subclinical mastitis was still present in the udder.

The results of our study indicate that subclinical mastitis in cows has no effect on SAA but leads to an increased concentration of this protein in milk (MAA). The lack of significant correlations between SAA concentration and its isoform concentration in milk in subclinical mastitis is evidence that AA can be synthesized locally in the udder as a response to infection. Berry et al. (2005) stated that MAA concentration in the milk of healthy cows is low and that its increase to $>500$ $\mathrm{ng} / \mathrm{mL}$ is an indication of the immune response in the mammary gland. In studies conducted by Kováč et al. (2011), MAA concentration in cows without clinical signs of inflammation $(473.7 \mathrm{ng} / \mathrm{mL})$ was similar to that reported by Berry et al. (2005) as the threshold of which exceedance indicates the occurrence of inflammation. Significantly higher values of MAA compared with the values indicated by Berry et al. (2005), for both clinically healthy cows and cows with subclinical mastitis, have also been reported by Nazifi et al. (2008). In our own studies, the concentration of MAA in the milk of cows with subclinical mastitis was 2 times higher than that in the milk of the control cows (790.2 and $360.5 \mathrm{ng} / \mathrm{mL}$, respectively).

The increase of MAA level usually correlates with the increase in SCC in milk (Petersen et al., 2004; Suojala et al., 2008; Gerardi et al., 2009). In the present study, there was also a correlation between MAA and SCC in the samples of milk taken from cows infected with subclinical mastitis caused by CNS. However, the results of other authors show that in some cases a high level of MAA was found in milk from cows with no symptoms of mastitis and SCC was $<200,000$ cells/ mL of milk. Kováč et al. (2011) suggested that these quarters may have been affected by the inflammatory process earlier, as evidenced by high concentrations of amyloid A in milk before symptoms of inflammation and SCC increase in milk. The moderate correlation between SCC and MAA likely is attributable to differences in the length or severity of udder infection (Nielsen et al., 2004).

Therefore, MAA may be considered to be a significantly more sensitive and early marker of inflammation in the mammary gland than SCC in milk in both cows and sheep (Gerardi et al., 2009; Kováč et al., 2011; Miglio et al., 2013). The ability to detect a subclinical form of inflammation is extremely important because cows with no visible symptoms of the disease often go untreated (Miglio et al., 2013). It appears, therefore, that the possibility of routinely marking the MAA in milk and early detection of subclinical mastitis will help prevent persistent udder infection and the spread of pathogens in dairy herds.

The main inducer of hepatic synthesis of APP is proinflammatory properties of IL-6. The present study showed significantly higher concentrations of IL-6 in both milk (20 times) and serum (2.5 times) of cows with subclinical CNS mastitis compared with healthy cows. Research conducted by Hagiwara et al. (2001) confirmed high levels of IL-6 already in the first stage of infection. The mean concentration of this cytokine in the first day of the disease was 25 times higher in the milk samples and 5 times higher in the serum samples from cows with acute mastitis than that in the samples from normal cows. In addition, the concentration of IL-6 at the onset of clinical mastitis was higher in the milk samples than in the serum samples. The authors suggested that levels of IL- 6 in milk and serum of cows depend not only on the infection phase but also on the type of microorganisms causing mastitis. In a study conducted by Hagiwara et al. (2001), the concentration of IL-6 in both milk and serum was significantly higher for cows with mastitis caused by Escherichia coli, Klebsiella pneumoniae, Staph. aureus, and Streptococcus sp. but significantly lower for CNS. Moreover, no statistically significant differences in IL-6 concentrations between milk and serum samples from cows with CNS mastitis and from healthy cows were found. In turn, Osman et al. (2010), who examined 25 cows with subclinical mastitis and 15 cows with clinical mastitis infected with coagulase-positive Staphylococcus spp., reported significantly higher levels of IL-6 in milk of cows with subclinical mastitis $(30.8 \mathrm{ng} / \mathrm{mL})$ than in milk of cows with clinical mastitis $(18 \mathrm{ng} / \mathrm{mL})$ and healthy cows. Similar results were also observed by Sakemi et al. (2011). Thus, IL-6 can be considered to be an early but nonspecific indicator of various inflammatory states and a potential marker of the subclinical form of inflammation. 
In contrast, IL-10 is produced at a later time and regulates the course of inflammation. The increase in IL-10 concentration was noted for mammary gland infections caused by various species of pathogens, including E. coli, K. pneumoniae, Pseudomonas aeruginosa, and Streptococcus sp. (Bannerman, 2009). However, initial and maximal increases in IL-10 production are consistently detected earlier in response to gram-negative bacteria than to gram-positive bacteria. Also interesting is the fact that induction of IL-10 is absent or delayed in cows with the greatest persistent concentrations of bacteria in milk (Bannerman, 2009). Among other things, detectable increases in IL-10 expression in the case of Staph. aureus IMI were not stated (Bannerman, 2009). This is confirmed by our study, which showed lower levels of IL-10 in serum and milk of cows with subclinical mastitis induced by CNS in comparison with healthy cows $(P<0.05$ and $P<$ 0.01 , respectively).

Also, IL-4 levels in our study were significantly lower in serum as well as in milk of infected cows compared with normal cows. These findings are conclusive because a similar pattern of expression of IL-4 and IL-10 would be expected because these IL produced by Th2 lymphocytes are responsible for the humoral immune response. Interleukin-4 activates the formation of lymphocytes, which is why it is often referred to as B-cell stimulating factor and B-cell growth factor. It is produced by Th2 and natural killer T-cells as well as by mast cells and basophils. The effect of IL- 4 is to stimulate B-cell proliferation, and it is one of the most important factors stimulating the production of $\operatorname{IgE}$ antibodies. Interleukin-4 also affects endothelial cells, inducing the expression of very late antigen-4 integrin, which is involved, among other things, in migration to tissues of eosinophils, monocytes, and T-cells. This cytokine also participates in hemopoesis, which affects the production of blood cells. In a study conducted by Fonseca et al. (2009), expression of the IL-4 gene showed a trend to be lower in cows with mastitis compared with healthy animals, but this difference was not significant.

Further studies are necessary to better characterize and understand the functions of cytokines in an immune response to an etiological factor of mastitis in cows. No studies of this type are yet available; therefore, the results cannot be compared with other studies.

In conclusion, our findings suggest that cows with subclinical mastitis caused by CNS develop a local immune response in the mammary gland in response to the pathogen. We have reported an increase in the level of MAA and proinflammatory cytokine IL-6 in the milk of unhealthy cows. Results of our study show that both MAA and IL- 6 may be used in the future as a diagnostic marker of subclinical mastitis. Systematic control of these proteins in the milk of dairy cows could detect subclinical inflammatory conditions of the mammary gland and in this way limit the occurrence of persistent mastitis and the spread of microorganisms in the environment.

\section{ACKNOWLEDGMENTS}

Financial support was provided by the core budget of Department and Clinic of Animal Reproduction, (Faculty of Veterinary Medicine, University of Life Sciences, Lublin, Poland).

\section{REFERENCES}

Bannerman, D. D. 2009. Pathogen-dependent induction of cytokines and other soluble inflammatory mediators during intramammary infection of dairy cows. J. Anim. Sci. 87(Suppl.):10-25.

Berg, L. C., P. D. Thomasen, P. H. Andersen, H. E. Jensen, and S. Jacobsen. 2011. Serum amyloid A is expressed in histologically normal tissues from horses and cattle. Vet. Immunol. Immunopathol. 144:155-159.

Berry, E. A., J. E. Hillerton, and P. Torgerson. 2005. Use of acute phase proteins in bovine milk. Pages 25-30 in Proc. British Mastitis Conference, Warwickshire, United Kingdom.

Bochniarz, M., W. Wawron, and M. Szczubiał. 2013. Coagulase-negative staphylococci (CNS) as an aetiological factor of mastitis in cows. Pol. J. Vet. Sci. 16:487-492.

Dąbrowski, R., J. Pastor, M. Szczubiał, T. Piech, M. Bochniarz, W. Wawron, and A. Tvarijonaviciute. 2015. Serum IL-6 and IL-10 concentrations in bitches with pyometra undergoing ovariohysterectomy. Acta Vet. Scand. 57:61.

De Vliegher, S., H. Laevens, L. A. Devriese, G. Opsomer, J. L. M. Leroy, H. W. Barkema, and A. de Kruif. 2003. Prepartum teat apex colonization with Staphylococcus chromogenes in dairy heifers is associated with low somatic cell count in early lactation. Vet. Microbiol. 92:245-252.

Eckersall, P. D., F. J. Young, C. McComb, C. J. Hogarth, S. Safi, A. Weber, T. McDonald, A. M. Nolan, and J. L. Fitzpatrick. 2001. Acute phase proteins in serum and milk from dairy cows with clinical mastitis. Vet. Rec. 148:35-41.

Eklund, K. K., K. Niemi, and P. T. Kovanen. 2012. Immune functions of serum amyloid A. Crit. Rev. Immunol. 32:335-348.

Ezzat Alnakip, M., M. Quintela-Baluja, K. Böhme, I. Fernandez-No, S. Caamaño-Antelo, P. Calo-Mata, and J. Barros-Velázquez. 2014. The immunology of mammary gland of dairy ruminants between healthy and inflammatory conditions. J. Vet. Med. 2014:659801.

Fonseca, I., P. V. Silva, C. C. Lange, M. F. Guimarães, M. M. Del, C. A. Weller, K. R. Silva Sousa, P. S. Lopes, J. D. Guimarães, and S. E. F. Guimarães. 2009. Expression profile of genes associated with mastitis in dairy cattle. Genet. Mol. Biol. 32:776-781.

Gentilini, E., G. Denamiel, A. Betancor, M. Rebuelto, M. R. Fermepin, and R. A. de Tores. 2002. Antimicrobial susceptibility of coagulase-negative staphylococci isolated from bovine mastitis in Argentina. J. Dairy Sci. 85:1913-1917.

Gerardi, G., D. Bernardini, C. A. Elia, V. Ferrari, L. Iob, and S. Segato. 2009. Use of serum amyloid A and milk amyloid A in the diagnosis of subclinical mastitis in dairy cows. J. Dairy Res. $76: 411-417$.

Grönlund, U., C. Hulten, P. D. Eckersall, C. Hogarth, and K. W. Persson. 2003. Haptoglobin and serum amyloid A in milk and serum during acute and chronic experimentally induced Staphylococcus aureus mastitis. J. Dairy Res. 70:379-386. 
Hagiwara, K., H. Yamanaka, K. Hisaeda, S. Taharaguchi, R. Kirisawa, and H. Iwai. 2001. Concentration of IL-6 in serum and whey from healthy and mastitic cows. Vet. Res. Commun. 25:99-108.

Kjelgaard-Hansen, M., M. Luntang-Jensen, J. Willesen, and A. L. Jensen. 2007. Measurement of serum interleukin-10 in the dog. Vet. J. 173:361-365.

Kováč, G., C. Tóthová, O. Nagy, and H. Seidel. 2011. Milk amyloid A and selected serum proteins in cows suffering from mastitis. Acta Vet. Brno 80:3-9.

Kovačević-Filipović, M., V. Ilić, Z. Vujčić, B. Dojnov, M. StevanovPavlović, Z. Mijačević, and T. Božić. 2012. Serum amyloid A isoforms in serum and milk from cows with Staphylococcus aureus subclinical mastitis. Vet. Immunol. Immunopathol. 145:120-128.

Loisa, P., T. Rinne, S. Laine, M. Hurme, and S. Kaukinen. 2003. Anti-inflammatory cytokine response and the development of multiple organ failure in severe sepsis. Acta Anaesthesiol. Scand. 47:319-325.

Makovec, J. A., and P. L. Ruegg. 2003. Results of milk samples submitted for microbiological examination in Wisconsin from 1994 to 2001. J. Dairy Sci. 86:3466-3472.

McDonald, T. L., M. A. Larson, D. R. Mack, and A. Weber. 2001. Elevated extrahepatic expression and secretion of mammary-associated serum amyloid A (M-SAA3) into colostrum. Vet. Immunol. Immunopathol. 83:203-211.

Miglio, A., L. Moscati, G. Fruganti, M. Pela, E. Scoccia, A. Valiani, and C. Maresca. 2013. Use of milk amyloid A in the diagnosis of subclinical mastitis in dairy ewes. J. Dairy Res. 80:496-502.

Moon, J. S., A. R. Lee, H. M. Kang, E. S. Lee, M. N. Kim, Y. H. Paik, Y. H. Park, Y. S. Joo, and H. C. Koo. 2007. Phenotypic and genetic antibiogram of methicillin-resistant staphylococci isolated from bovine mastitis in Korea. J. Dairy Sci. 90:1176-1185.

Murata, H., N. Shimada, and M. Yoshioka. 2004. Current research on acute phase proteins in veterinary diagnosis: An overview. Vet. J. $168: 28-40$

Nazifi, S., A. Khoshvaghti, and H. R. Gheisari. 2008. Evaluation of serum and milk amyloid A in some inflammatory diseases of cattle. Iran. J. Vet. Res. 9:222-226.

Nielsen, B. H., S. Jacobsen, P. H. Anderson, T. A. Niewold, and P. M. Heegaard. 2004. Acute phase protein concentrations in serum and milk from healthy cows, cows with clinical mastitis and cows with extramammary inflammatory conditions. Vet. Rec. 154:361-365.

Niemiałtowski, M., B. J. Nonnecke, and S. P. Targowski. 1988. Phagocytic activity of milk leukocytes during chronic staphylococcal mastitis. J. Dairy Sci. 71:780-787.
Osman, K. M., H. M. Hassan, I. M. Ibrahim, and M. M. S. Mikhail. 2010. The impact of staphylococcal mastitis on the level of milk IL-6, lysozyme and nitric oxide. Comp. Immunol. Microb. Infect. Dis. 33:85-93.

Paape, M. J., D. D. Bannerman, X. Zhao, and J. W. Lee. 2003. The bovine neutrophil: Structure and function in blood and milk. Vet. Res. 34:597-627.

Petersen, H. H., J. P. Nielsen, and P. M. Heegaard. 2004. Application of acute phase protein measurements in veterinary clinical chemistry. Vet. Res. 35:163-187.

Pyörälä, S., and S. Taponen. 2009. Coagulase-negative staphylococciEmerging mastitis pathogens. Vet. Microbiol. 134:3-8.

Sakemi, Y., Y. Tamura, and K. Hagiwara. 2011. Interleukin-6 in quarter milk as a further prediction marker for bovine subclinical mastitis. J. Dairy Res. 78:118-121.

Scheller, J., A. Chalaris, D. Schmidt-Arras, and S. Rose-John. 2011 The pro- and anti-inflammatory properties of the cytokine interleukin-6. Biochim. Biophys. Acta 1813:878-888.

Shuster, D. E., E. K. Lee, and M. G. Stevens. 1993. Cytokine production during endotoxin-induced mastitis in lactating dairy cows. Am. J. Vet. Res. 54:80-85.

Song, M., and J. A. Kellum. 2005. Interleukin-6. Crit. Care Med. 33(12 Suppl.):S463-S465.

Suojala, L., T. Orro, H. Järvinen, J. Saatsi, and S. Pyörälä. 2008 Acute phase response in two consecutive experimentally induced $E$. coli intramammary infections in dairy cows. Acta Vet. Scand. 50:18-28.

Thorberg, B. M., M. L. Danielsson-Them, U. Emanuelson, and K. P. Waller. 2009. Bovine subclinical mastitis caused by different types of coagulase-negative staphylococci. J. Dairy Sci. 92:4962-4970.

Tomazi, T., J. L. Gonçalves, J. R. Barreiro, M. A. Arcari, and M. V. dos Santos. 2015. Bovine clinical intramammary infection caused by coagulase-negative staphylococci increases somatic cell count but has no effect on milk yield or composition. J. Dairy Sci. 98:3071-3078.

Tóthová, C. S., O. Nagy, H. Seidel, and G. Kováč. 2014. Acute phase proteins and their use in the diagnosis of diseases in ruminants: A review. Vet. Med. Czech. 59:163-180.

Waller, K. P., A. Aspan, A. Nyman, Y. Persson, and U. G. Andersson. 2011. CNS species and antimicrobial resistance in clinical and subclinical bovine mastitis. Vet. Microbiol. 152:112-116.

Winter, P., K. Fuchs, K. Walseh, and I. G. Colditz. 2006. Production of serum amyloid A in serum and milk during experimental Staphylococcus epidermidis mastitis in ewes. Res. Vet. Sci. 81:321-326. 